\title{
EFFECTS OF CHANGE MANAGEMENT PRACTICES ON ORGANIZATIONAL PERFORMANCE: THE CASE OF ETHIO TELECOM SOUTH REGION ETHIOPIA
}

\author{
Aman Gemechu \\ Department of Research \\ Defense Ministry, Addis Ababa, Ethiopia
}

\author{
Mustefa Ibrahim Wake \\ Ministry of Education, Addis, Ababa \\ Ethiopia
}

\begin{abstract}
The main objective of this study was to investigate the effect of change management practices on organization performance in the case of ethio telecom south region. To attain this objective, 50 males and 19 females totally (69) respondents were selected using simple random sampling. The population of the study was employees, supervisors and managers of ethio telecom south region. Simple Random sampling was used to select the appropriate sample of the respondent and the shops were selected by purposive sampling with respect to balanced scorecard management practices, kaizen philosophy management practice and standard quality circle management practice. Descriptive research designs as well qualitative and quantitative research approach were employed in conducting the study. Data was collected using questionnaires and interviews and analyzed using SPSS Version 24. Descriptive analysis namely percentage, mean, standard deviation and inferential analysis namely multiple linear regression were employed. The study indicated that balanced scored cared, kaizen and standard quality circle management practiced in ethio telecom south region occasionally. Moreover, this study revealed that balanced scored cared, kaizen and standard quality circle management practice contributed to ethio telecom south region organizational performance to a great extent. The study also showed that there was significant relationship between balanced scored cared, kaizen and standard quality circle management practices and organizational performance of ethio telecom south region. This study further revealed that balanced scored card, kaizen and standard quality circle management practices had a positive effect on organizational performance of ethio telecom south region. Likewise, this study showed that kaizen management practice is statistically significant in predicting organizational performance. More importantly, this study recommended ethio telecom south region to practice the balanced scorecard, kaizen and standard quality circle management regularly.
\end{abstract}

Keywords - Change management practices, organizational performance

\section{INTRODUCTION}

Different studies shows that strategic change management is an emerging field and is increasingly being perceived as a working tool that provides solutions to a variety of issues affecting organizations today (Burnes,2014). According to him, change management encompasses the organizational tools that can be used to assist people make successful personal change over, acceptance and realization of change. He further confirmed that, the internal state of an organization and its external environment affects the strategic change. According to (Bashir and Afzal, 2011), Change management makes it easier for organizations to achieve success in meeting demand and face internal and external challenges. Mullins \& Christy (2014) confirmed change management as the procedure, techniques and tools to manage the employee side of variation to attain the required organizational objective. Moreover, Hiatt and Creasey (2012) stated that change management is a set of tools, practices and methods to manage the people side of change that are important to transit individuals from a current state to the preferred future one to achieve objectives of a needed change. According to (Sidikova, 2011), change is what presses us out of our comfort zone and it is inevitable.

According to Raftery (2009) the undergoing a new change is the most difficult topic and it is questionable of success and it always has enemies whom are beneficiaries from the old system. Thus, Garber (2013) cited that change is expected in the workplace, so the responsibility of the manager is to hold the change by making the conversion process easier. Therefore, change management is taking a proactive approach about how the change is treated within an organization. It involves adapting to the change and monitoring the need for change within an organization; starting that change and then controlling it (Hiatt and Creasey, 2012). 


\section{International Journal of Engineering Applied Sciences and Technology, 2021 \\ Vol. 5, Issue 12, ISSN No. 2455-2143, Pages 53-62 \\ Published Online April 2021 in IJEAST (http://www.ijeast.com)}

Garber (2013), proved that these days' telecommunication companies observer dramatic changes at all levels and there are many drivers for change in the telecommunication sector; caused by technological advancement, cruel competition that has risen radically in the last years, and the need to develop new services in the telecommunication sector (Hodges, 1995). Some studies also shows that telecommunication organizations need sharp reactions to manage with the fast changing technologies and organization skills and therefore, change management is a vital instrument to be adopted by the telecommunication division to maintain development and growth and according to the authors, as organizational changes have become more frequent and a necessity for survival, the argument of employees in this sector has become an important human resources management function and a priority for top management to increase chances of success of different change projects (Tang and Gao, 2012).

In November 29/2011,'the former Ethiopian Telecommunications Corporation was rebranded itself to the new company known as "' ethio telecom", which was part of the transformation process of the company. Although ethio telecom undergoes various incremental changes in its life time, the original company structure is extended to the level of regions, zones, head quarters, shops and departmental divisions proposed by France telecom (Orange) during its transformational change in the year 2011-2013 and each division under the respective zones, regions and headquarter is composed of various departments based on its complexity of work flow and scope Taye Estifanos Dubale (2010). On the other hand, ethio telecom is one of the companies implementing change management practices such as balanced scorecard and kaizen philosophy in Ethiopia to realize over all continuous improvement in its performance. Even though ethio telecom established and availed all the above desired requirements, the company is facing problems during implementation (Annual report, 2016 and 2017). According to the company annual reports kaizen is not being practical as it is planned in general and that the established standard quality circles are not bringing the change which the company aspired in particular. Due to the above mentioned factors are not well practiced in ethio telecom in graining the culture of kaizen. the researchers is expected to provide their own contribution by having conceptual and empirical evidence on the effects of change management practice on organizational performance and these problems motivated the researchers to undertake the research on the ethio telecom south region specifically on effects of balanced scorecard, kaizen philosophy and standard quality circle management practices and to address the observed problems in relation with the organizational performance.

\section{Statements of the problem}

Different studies confirmed that when an organization is poorly aligned to its environment, change is look forward to and the telecommunication industry is an important section of the information technology division that is sensitive to external environmental changes and According to (Hiatt \& Creasey, 2012) if change not done efficiently can lead to acceptance at a slower speed, low competence, poor operation of the system; stated simple, it results in less benefit from the change (Hiatt \& Creasey, 2012). Moreover, ethio telecom is one of the companies implementing change management systems to realize over all continuous improvement in its performance and for many years, ethio telecom's monopolistic control stifled innovation, restricted network expansion and limited the scope of services on offer (Maharastra, (2019). However, a management contract with orange group dramatically improved the company's performance, though there remain weaknesses in quality of service. The contract was considered a first step towards sector privatization, the introduction of competition, and though the government for many years rejected calls to progress along these lines, citing the need for higher profits from the company to subsidies unrelated projects, a shift emerged in mid-2018 with plans to sell a bet in the telecom as part of a wider economic reform Maharastra, (2019).

In this study, effects of change management practices on organizational performance and certain applications of the change tools such as processes, procedures and system in ethio telecom in general were studied. Many researches indicate that there are certain gaps in human side of the change in relation to the conceptual understanding and lack of adequate communication and minimizing resistance. For example, a study conducted by Maryam Beshtawi and Ayham Jaaron (2014) discusses findings in relation to the gaps in current management condition, capacity building issues, communication and human resistance to change. However, in this study certain gaps in using performance tools such as balanced score card, quality circle and application of the kaizen philosophy in the selected region of ethio telecom to assist effective change were also studied. In addition, from the researchers observation 'in Shashemene shops of ethio telecom south region and the employee suggestions reveal that, certain gaps of practicing are creating difficulties in achieving the required goal as per the need and interest of the company. Therefore, as to the knowledge and understanding of the researchers, a study has not been conducted yet with regard to effect of balanced score card, kaizen philosophy and standard quality circle management practices on organizational performance. To this end the study guided by the following research questions:

1. What is the position of change management practices in ethio telecom of South region?

2. What is the relationship between change management practices and organizational performance in ethio telecom of south region? 


\section{International Journal of Engineering Applied Sciences and Technology, 2021 \\ Vol. 5, Issue 12, ISSN No. 2455-2143, Pages 53-62 \\ Published Online April 2021 in IJEAST (http://www.ijeast.com)}

3. What are the effects of change management tools practices on performance in ethio telecon southern region?

4. What is the level of performance in ethio telecom of south region?

\section{HYPOTHESIS OF THE STUDY}

To assess the change management practices that are adopted by ethio telecom of south region, the researcher investigated the relationship between current change management practices and its effect on organizational performance in the ethio telecom of south region. Therefore, independent variables (Balanced score card, Kaizen and Standard Quality Circle management practice) and the dependent variable is organizational performance were developed and examined.

$\mathrm{H}_{\mathrm{o}}$ : A balanced Scorecard management practice does not have any significant effect on organizational performance in ethio telecom south region.

$\mathrm{H}_{0}$ : A Kaizen management practice does not have any significant effect on organization performance in ethio telecom south region.

$\mathrm{H}_{\mathrm{o}}$ : Standard Quality Circle management practices do not affect positively organizational performance in ethio telecom south region.

\section{Objective of the Study}

\section{General Objective}

The major purpose of this study is to investigate the effect of change management practices on organizational performance in ethio telecom of south region.

\section{Specific Objectives}

Specifically this study is intended to:

1. Assess the change management practices in ethio telecom South region.

2. Examine the relationship between change management practices and organizational performance in ethio telecom south region.

3. Investigate the effects of change management tools practices on performance in ethio telecom south region.

4. To examine the level of performance in ethio telecom of south region.

\section{Significance of the Study}

Since there is no study conducted previously on the particular issues specifically in the selected shops of south region of ethio telecom. Therefore, the result of this study has the following importance: It helps to create awareness in reducing factor affecting the effectiveness of change management practices and organizational performance in ethio telecom south region. The employees and executives of south region ethio telecom shops in particular shall be advised to create awareness and implement the change management tools to ensure the continuous improvement of their respective departments or sections under their domain. This study can have academic and certain social contribution. Furthermore, different stakeholders including strategic customers can be benefiting from this research. More importantly, this study shall be provides preliminary backgrounds which give out as spring board for other researchers who are interested in the future studies

\section{RESEARCH DESIGN AND PROCEDURES}

\subsection{Introduction}

This part of the study deals with an overview of the research design, research population, sample and sampling techniques, data collecting instruments and analysis procedures. Thus, in order to address the research questions, the concerned organization (ethio telecom south region was used in collecting data. In doing this, mixed approach research technique was applied to analyze the data. Hence, the populations of the study were employee of ethio telecom southern region. The administration of data collection was guided by ensuring consents from expert and sample members. The ethical considerations to be followed were set and practiced during data gathering processes.

\subsection{Research Design contextual concept}

Research design is considered as the blueprint and cornerstone of any study since it facilitates various research operations. In this regard, Kothari (2006) argues that research design helps the researcher for advance planning of the methods to be adopted for collecting the relevant data and techniques to be used during analysis. The nature and objectives of the work to be studied and the means of obtaining information are the most important factors to be considered in order to choose the appropriate research design; accordingly, all the staff members of the branch shops were contacted using different methods of data collection. All the permanent employees of the selected shops who were target population for this assessment were included under the design considering easiness of the management for data analysis due to small number of the available target population in the shops under choice.

\subsection{Sampling Techniques and Sample Size Determination}

According to Mugenda and Mugenda (2003), who argues that at least $10 \%$ of the total population is considered as a representative of the population. Thus, $10 \%$ of the accessible population is enough for the sample size. This study used $10 \%$ of the target population as sample size. The total numbers of target population under study were 684 (535 Male and 149 


\section{International Journal of Engineering Applied Sciences and Technology, 2021 \\ Vol. 5, Issue 12, ISSN No. 2455-2143, Pages 53-62 \\ Published Online April 2021 in IJEAST (http://www.ijeast.com)}

Female) employees of ethio telecom south region and of 18 shops. Five shops of south region ethio telecom namely Negelle Arsi, Kofale, Shashamane, Awasho and Awwasa were selected through purposive sampling method because of their long term experience in providing service to its customers. Furthermore, from the target population of 684 the researchers were proportionally selected 69 (50 males and 19 females) employees from each five shops using simple random sampling for the questionnaires. Moreover, five respective shop's managers were selected as a key informant for the interview.

\subsection{Data sources and methods of Collection}

\subsubsection{Data Gathering Tools}

Both primary and secondary sources were used in the study. Primary data were gathered from managers, supervisors and employees who are supposed to be data source of this study. The researchers used the data collecting instrument such as questionnaire and interview to collect the primary data. Secondary data were gathered from different literatures such as books, journals, research reports and documents to develop chapter two of this research that is the review of related literature. The instruments were developed by the researchers through english for the employees whereas; the prepared tools were translated in to afaan Oromo and amharic languages for the selected samples of employees for the convenience of communication.

\subsubsection{Data collection methods:}

Both primary and secondary sources were used in the study. Primary data was gathered from employee of the company out of the selected population who were supposed to be data source of this study. The researcher used the data collecting instrument such as questionnaire and interview to collect the primary data.

Secondary data was gathered from different literatures such as books, journals, research reports and documents to develop the $2^{\text {nd }}$ chapter of this research that is review of related literature.

\subsubsection{Procedure for Data Collection}

The first step towards the collection of necessary data was to make face to face contact with employee of the selected shops. On the other hand, coordinators and senior experts were contacted for the task introducing the purpose of this study and to facilitate necessary condition during data collection. Some of the employees and strategic customers who look for explanations on some declarations were given the necessary attention. The completed questionnaire was filled and returned on the same day via e-mail for the employee of the shop and physical contact with the selected samples of customers and strategic partners. The heads of the selected telecom shops were given information as a key informant interview.

\subsection{Pilot Study}

Although it is optional for the researcher, the pre-testing of the questionnaire was conducted with 20 respondents of bule hora ethio telecom shop employees and supervisors which were selected randomly from among the shops available in the south regional office. These respondents were not part of the actual sample of the study. One of the main issues concerns the scale's internal consistency. This refers to the degree to which the items that make up the scale hang together. One of the most commonly used indicators of internal consistency is Cronbach's alpha coefficient For this analysis, cronbach's alpha value shown in the reliability statistics Table is 0.821 , suggesting good internal consistency reliability for the scale with this sample. Moreover, Respondents were encouraged to make useful suggestions by submitting written comments on items with ambiguities.

Table: 1 Reliability Statistics

\begin{tabular}{|l|c|c|c|}
\hline Dimension & $\begin{array}{l}\text { No of } \\
\text { item }\end{array}$ & $\begin{array}{l}\text { Crombach } \\
\text { Alph }\end{array}$ & Remark \\
\hline \multicolumn{1}{|c|}{ BSC } & 6 & 0.823 & Accepted \\
\hline $\begin{array}{l}\text { Kaizen } \\
\text { management } \\
\text { practices }\end{array}$ & 7 & .821 & Accepted \\
\hline $\begin{array}{l}\text { SQCManagement } \\
\text { Practices }\end{array}$ & 6 & .820 & Accepted \\
\hline $\begin{array}{l}\text { SQC } \\
\text { Management } \\
\text { practices }\end{array}$ & 19 & .821 & Accepted \\
\hline
\end{tabular}

\subsection{Methods of Data Analysis}

The collected data analyzed and interpreted by using both quantitative and qualitative techniques. The quantitative part which was collected using questionnaire is first interned in to a computer using SPSS version 24 software. Further analysis is also done using this software program. Simple Tables are used to analysis and present the data. The qualitative data is analyzed manually. First, all the interview were transcribedwritten as they are in working language amharic. Second, all the transcriptions were translated in to English using Google translation for further analysis.

The analysis is done by repeatedly reading the translations and understanding the common and different issues raised by the managers and supervisors. The finding of the qualitative part is mostly used to supplement the quantitative part. Furthermore, to analyze and interpret the quantitative data obtained from respondents,' descriptive and inferential statistics were used. Arithmetic mean, standard deviation, and simple percentage were used. Simple percentage used to classify and analyze the relative standard characteristics of respondents such as sex, age, experience, educational qualification, work division and position of the sample 
population. In Inferential statistical analysis, ANOVA, correlation and multiple linear regression analysis were used to determine the relationship between the independent variable (change management practices) and dependent variable (organizational performance); and to test the effect of change management practices on organizational performance respectively. In line with this, all responses to open and closed ended items were organized, summarized and presented by narrating based on their thematic area.

\section{RESULTS AND DISCUSSIONS}

Result regarding to question entitled the effects of change management tools practices on performance in ethio telecom south region. Mean and standard deviation were used in answering these questions as Table 2 displayed the results.

\subsection{Results concerning Balanced Score card Management practices}

This study sought to find out the state of BSC management practices in ethio telecom of south region. The responses from respondents were analyzed as shown in Table two below.

Table: 2. Balanced Scorecard Management practices

\begin{tabular}{|c|c|c|c|}
\hline Items & No & ${ }_{a n}{ }^{M e}$ & $\begin{array}{l}\quad \text { Std } \\
\text {.Deviat } \\
\text { ion }\end{array}$ \\
\hline $\begin{array}{ll}\text { Training on } & B S C \\
\text { implementation } & \\
\end{array}$ & 66 & $09^{1.4}$ & $495^{-}$ \\
\hline $\begin{array}{l}\text { BSC strategic themes } \\
\text { of organization }\end{array}$ & 66 & $09^{3.4}$ & 1.10 \\
\hline $\begin{array}{lr}\text { BSC } & \text { enables } \\
\text { organization } & \text { clarify } \\
\text { their vision } & \\
\end{array}$ & 66 & $94^{3.8}$ & $611^{-}$ \\
\hline $\begin{array}{l}\text { BSC provide feedback } \\
\text { for organizational } \\
\text { performance }\end{array}$ & 66 & $06^{4.1}$ & $747^{-}$ \\
\hline $\begin{array}{l}\text { Clarity of employee } \\
\text { about organization's } \\
\text { objectives } \\
\text { individual goals }\end{array}$ & 66 & $38^{4.1}$ & .80 \\
\hline $\begin{array}{l}\text { The employee } \\
\text { performancer linked } \\
\text { with BSC practice }\end{array}$ & 66 & $33^{4.3}$ & .88 \\
\hline Overall practices & 66 & $78^{3.5}$ & $5^{.77}$ \\
\hline
\end{tabular}

Source: SPSS Version 24 output, there searcher's survey result (2020)
As revealed from Table 2 above, training on Balanced scorecard implementation was practiced with relatively low with mean value $(\mathrm{Mean}=1.409, \mathrm{SD}=0.495)$. This implies that the ethio telecom south region were not continually give the training to the employees in order to capable them, followed by Balanced scorecard strategic themes of organization of an organization $(\mathrm{Mean}=3.409, \mathrm{SD}=1.109)$ was practiced occasionally. Concerning balanced scorecard enables organization clarify their vision and mission respondents reported $(\mathrm{Mean}=3.894, \mathrm{SD}=0.611)$ were relatively very often practiced. Balanced scorecard provide feedback for organizational performance $(\mathrm{Mean}=4.106, \mathrm{SD}=0.7469)$ and clarity of employee about organization's objectives and individual goals $(\mathrm{Mean}=4.318, \mathrm{SD}=0.8069)$. With regard to the employee performance linked with Balanced scorecard practice $(\mathrm{Mean}=4.333, \mathrm{SD}=0.8829)$ were very often practiced.

From the above Table, an overall mean and standard deviation of (Mean=3.578, $\mathrm{SD}=0.775)$ was recorded indicating that balanced scorecard management practices were very often practiced and contributed to ethio telecom south region performance at a great extent. This result can be supported by previous research. According to (Kumari, 2011) the Balanced scorecard translates an organization's mission and strategy into a comprehensive set of performance measures that provides the framework for a strategic measurement and management system. From chapter two in review of literature, according to balanced score card training manual of Ethiopian management institute (2014), balanced scored card is a strategic planning and management system that is used extensively in business industry, government and nonprofit organizations worldwide to align business activities to the vision and strategy of the organization, improve internal and external communications and monitor organization performance against strategic goals.

\subsection{Results related to the kaizen management practices.}

Kaizen philosophy management practices in ethio telecom of south region. Mean and standard deviation where used in analyzed as shown in Table 3 below. 
Table 3: Kaizen philosophy Management Practice

\begin{tabular}{|c|c|c|c|}
\hline $\begin{array}{l}\text { Kaizen philosophy Management } \\
\text { Practice }\end{array}$ & $o$ & $\begin{array}{c}M \\
\text { ean }\end{array}$ & $\begin{array}{l}\text { Std. } \\
\text { Deviati } \\
\text { on }\end{array}$ \\
\hline $\begin{array}{ll}\text { Kaizen } & \text { philosophy } \\
\text { implementation } & \end{array}$ & 6 & $\begin{array}{r}1 \\
.030\end{array}$ & .173 \\
\hline $\begin{array}{l}\text { Proper and fair way of } \\
\text { motivating employees for their } \\
\text { achievement of practicing kaizen }\end{array}$ & 6 & $\begin{array}{l}3.74 \\
2\end{array}$ & .829 \\
\hline $\begin{array}{l}\text { Kaizen becomes the working } \\
\text { culture in organization }\end{array}$ & 6 & $\begin{array}{l}3.86 \\
4\end{array}$ & 911 \\
\hline $\begin{array}{l}\text { Ever individual involved in the } \\
\text { implementation of Kaizen }\end{array}$ & 6 & $\begin{array}{l}3.86 \\
4\end{array}$ & .579 \\
\hline $\begin{array}{l}\text { By applying } 5 S \text {, internal office } \\
\text { and compound is clean and } \\
\text { attractive }\end{array}$ & 6 & $\begin{array}{l}3.87 \\
9\end{array}$ & .886 \\
\hline $\begin{array}{l}\text { Management commitment to } \\
\text { implement kaizen in the company }\end{array}$ & 6 & $\begin{array}{l}3.90 \\
9\end{array}$ & .854 \\
\hline $\begin{array}{l}\text { Employees well understood } \\
\text { Kaizen philosophy }\end{array}$ & 6 & $\begin{array}{l}3.93 \\
9\end{array}$ & .821 \\
\hline Over all & $6^{6}$ & $\begin{array}{l}3.46 \\
1 \\
\end{array}$ & .722 \\
\hline
\end{tabular}

Source: SPSS Version 24 output, the researcher's survey result (2020)

As shown from the Table 3 above, kaizen philosophy implementation was practiced with relatively low mean (Mean=1.030, SD=.173). Interview result confirmed that incentive plan is not implemented in the standard quality circles and it has already begun to be implemented on the cross cutting quality circles and there is a plan to cascade to the quality circles in the near future. Moreover, it can be inferred that, kaizen has been implemented some few years before in the company, doesn't have proper way of motivational and recognition plan for their contribution and this can be considered as a source for the inconsistency of proactive manner of employees towards continuous improvement mindset.

Followed by Proper and fair way of motivating employees for their achievement of practicing kaizen (Mean= 3.742, SD= .829). Kaizen becomes the working culture in organization $(\mathrm{Mean}=3.864, \mathrm{SD}=0.911)$. Every individual involved in the implementation of Kaizen (Mean=3.864, $\mathrm{SD}=0.579$ ), by applying $5 \mathrm{~S}$, internal office and compound is clean and attractive $($ Mean $=3.879, \mathrm{SD}=0.886)$ and management commitment to implement kaizen in the company (Mean= 3.909, $\mathrm{SD}=0.854$ ) and Employees well understood Kaizen philosophy were very often practiced respectively. From the above Table, an overall mean and standard deviation of (Mean=3.461, $\mathrm{SD}=0.722$ ) recorded indicating that kaizen philosophy management practices were occasionally practiced and contributed to ethio telecom south region organizational performance as a moderate extent.

On the same Table above the analysis also showed that standard deviation spread from 0.173 to 0.911 which implies that respondents were more varied in their opinion to the responses given under kaizen philosophy management practices.

\subsection{Results related to the standard circle management practice.}

To assess the change management practices in ethio telecom South region. Employee was used in answering these questions and the results are displayed in Table 4 below.

Table 4: Standard Quality circle Management practice

\begin{tabular}{|c|c|c|c|}
\hline $\begin{array}{l}\text { Standard quality circle } \\
\text { management practice }\end{array}$ & $\begin{array}{l}N \\
o\end{array}$ & Mean & $\begin{array}{l}\text { Std. } \\
\text { Deviation }\end{array}$ \\
\hline $\begin{array}{l}\text { Participation in quality } \\
\text { circle Meeting }\end{array}$ & $\begin{array}{l}6 \\
6\end{array}$ & 1.045 & 0.210 \\
\hline $\begin{array}{l}\text { Quality circle meeting is } \\
\text { effective in problem solving }\end{array}$ & $\begin{array}{l}6 \\
6\end{array}$ & 1.091 & 0.290 \\
\hline $\begin{array}{l}\text { Standard quality circles are } \\
\text { meeting regularly to } \\
\text { improve performance }\end{array}$ & $\begin{array}{l}6 \\
6\end{array}$ & 3.076 & 1.086 \\
\hline $\begin{array}{l}\text { Management provide } \\
\text { feedback for issues raised } \\
\text { in SQC meeting to improve } \\
\text { performance }\end{array}$ & $\begin{array}{l}6 \\
6\end{array}$ & 3.742 & \\
\hline $\begin{array}{l}\text { SQC meetings are held with } \\
\text { the sense for better } \\
\text { improvement }\end{array}$ & $\begin{array}{l}6 \\
6 \\
\end{array}$ & 3.788 & 0.569 \\
\hline $\begin{array}{l}\text { Management implement } \\
\text { employees recommendation } \\
\text { to improve performance }\end{array}$ & $\begin{array}{l}6 \\
6\end{array}$ & 3.879 & 09.03 \\
\hline Over all & $\begin{array}{l}6 \\
6\end{array}$ & 2.77 & 0.673 \\
\hline
\end{tabular}

Source: SPSS Version 24 output, the researcher's survey result (2020)

Here the participation of all members of the company together with standard quality circles towards implementation of standard quality circle in the company is assessed. Respondents are provided with six statements to assess the participation, implementation of suggestions as well as the objectives of standard quality circles meeting in delivering improvement ideas. As shown from the Table 4, Participation in quality circle meeting mean $($ Mean $=1.045, \mathrm{SD}=0.210)$ and Quality circle meeting is effective in problem resolving (Mean=1.091, SD=0.290) were almost at the level of never practiced with relatively low mean respectively. 
Standard quality circles are meeting regularly to improve performance $(\mathrm{Mean}=3.076, \mathrm{SD}=1.086)$ were occasionally practiced. Management provide feedback for issues raised in standard quality circle meeting to improve performance (Mean=3.742, $\mathrm{SD}=$ 0.982).As mentioned by Okada 2004, Meetings constitute one of the crucial aspects of QC Circle activity, which, itself, involves a group of people in the same workshop who share common interests and objectives. Standard quality circle meetings are held with the sense for better improvement (Mean= 3.788, $\mathrm{SD}=0.569)$ and Management implement employees recommendation to improve performance (Mean $=3.879, \mathrm{SD}=0.903$ ) were very often practiced respectively. From the Table 4 above, an overall mean and standard deviation of

Table: 5. ANOVA Model fit

\begin{tabular}{|c|c|c|c|c|c|}
\hline & \multicolumn{5}{|c|}{$A N N O V A$} \\
\hline Model & $\begin{array}{l}\text { Sum of } \\
\text { Square }\end{array}$ & $D F$ & $\begin{array}{l}\text { Manasq } \\
\text { uan }\end{array}$ & $F$ & $i g^{S}$ \\
\hline $\begin{array}{ll}\text { A. } & \text { Re } \\
& \text { gre } \\
& \text { ssi } \\
& \text { on }\end{array}$ & 5.100 & 3 & 1.700 & 4.064 & $\begin{array}{l}.011 \\
b\end{array}$ \\
\hline $\begin{array}{ll}\text { B. } & \text { Res } \\
& i d u \\
& a l\end{array}$ & $1^{25.93}$ & $2^{6}$ & .418 & 2.6 & 1.3 \\
\hline Total & $0^{31.03}$ & $5^{6}$ & & & \\
\hline $\begin{array}{l}a . \\
b .\end{array}$ & $\begin{array}{l}\text { ependent } \\
\text { erformance } \\
\text { Predictors. } \\
\text { ces, Kaizenn } \\
\text { Ianagement }\end{array}$ & $\begin{array}{r}\text { Vart } \\
\text { Constc } \\
\text { ianage } \\
\text { practic }\end{array}$ & $\begin{array}{l}n t), S Q C m \\
\text { lentpracti } \\
\text { es }\end{array}$ & $\begin{array}{l}\text { Organiz } \\
\text { anageme } \\
\text { ces,BSC }\end{array}$ & ntprac \\
\hline
\end{tabular}

(Mean=2.770, $\mathrm{SD}=0.673$ ) was recorded indicating that Balanced scorecard management practices were occasionally practiced and it contributed to ethio telecom south region organizational performance moderate extent. The analysis also showed that standard deviation spread from 0.210 to 1.086 which implies that respondents were more varied in their opinion to the responses given under standard quality circle management practices. More importantly, As shown on the same from Table 4 above, an overall mean and standard deviation was recorded indicating thatstandard quality circle management practices was occasionally practiced.

\subsection{ANOVA Model fit}

The F-ratio in the below shows ANOVA Table tests whether the overall regression model is fit for the data. Accordingly,
Table 5 shows that the independent variables statistically significantly predict the dependent variable $=4.064, \mathrm{p}<.005$.

\subsection{Effect of Balanced Score Cared (BSC) Management Practices}

Table 6: One way Analysis of Variance Test of Hypotheses

\begin{tabular}{|c|c|c|c|c|c|}
\hline \multicolumn{6}{|l|}{$A N O V A$} \\
\hline $\begin{array}{l}\text { Between the } \\
\text { group }\end{array}$ & $\begin{array}{l}\text { Sum of } \\
\text { the } \\
\text { square }\end{array}$ & $\begin{array}{l}D e \\
f\end{array}$ & $\begin{array}{l}\text { Mean } \\
\text { squar } \\
e\end{array}$ & $F$ & $i g^{S}$ \\
\hline $\begin{array}{l}\text { Between the } \\
\text { group }\end{array}$ & 25.304 & 3 & 8.43 & 13.174 & $.00^{1}$ \\
\hline $\begin{array}{l}\text { Within the } \\
\text { group }\end{array}$ & 39.696 & 62 & .640 & & \\
\hline Total & 65,000 & 65 & & & \\
\hline
\end{tabular}

The analysis showed that balanced scorecard management practices significantly affect organizational performance in ethio telecom south region at $(\mathrm{P} \leq 0.05)$ confidence interval. This revealed that statistically the values of the response were different at $F=13$. 174 , probability value of 0.000 , hence the null hypothesis was rejected. This implies that Balanced scorecard management practice have significant effect on organizational performance in ethio telecom south region.

\subsection{Effect of Kaizen Management Practice}

Table 7: One way Analysis of Variance Test of Hypotheses

Source: Computer SPSSversion24.0 Output, field survey 2020.

\begin{tabular}{|c|c|c|c|c|c|}
\hline \multicolumn{5}{|c|}{ ANOVA } \\
\hline & $\begin{array}{l}\text { Sum of the } \\
\text { square }\end{array}$ & Def & $\begin{array}{l}\text { Mean } \\
\text { squar } \\
e\end{array}$ & $F$ & Sig \\
\hline $\begin{array}{l}\text { Between } \\
\text { the group }\end{array}$ & 16.002 & 4 & 4.001 & $\begin{array}{l}6.10 \\
8\end{array}$ & 0.00 \\
\hline $\begin{array}{c}\text { Within } \\
\text { the group }\end{array}$ & 39.952 & 61 & .65 & & \\
\hline Total & 55.955 & 65 & & & \\
\hline
\end{tabular}




\section{International Journal of Engineering Applied Sciences and Technology, 2021 \\ Vol. 5, Issue 12, ISSN No. 2455-2143, Pages 53-62 \\ Published Online April 2021 in IJEAST (http://www.ijeast.com)}

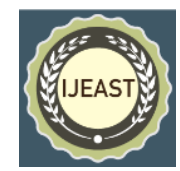

This hypothesis was intended to identify the strength of the effect of kaizen management practices on organization performance in south region ethio telecom. The ANOVA Table shows that kaizen management practices strongly affect organization performance in south region of ethio telecom at $(\mathrm{P} \leq 0.05)$ since the $\mathrm{F}=6.108$ probability values is 0.000 . The null hypothesis was rejected. This implies that kaizen philosophy management practice had significant effect on organizational performance in ethio telecom south region

\section{Effect of SQC Management Practices}

Table 8: One way Analysis of Variance Test of Hypotheses

\begin{tabular}{|c|c|c|c|c|c|}
\hline 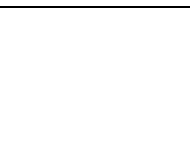 & \begin{tabular}{l}
\multicolumn{2}{c}{ Sum } \\
of the \\
square
\end{tabular} & Def & $\begin{array}{l}\quad M \\
\text { ean } \\
\text { squar } \\
e\end{array}$ & $F$ & Sig \\
\hline $\begin{array}{l}\text { Between } \\
\text { the group }\end{array}$ & 9.058 & 3 & 3.019 & $\begin{array}{l}8.06 \\
9\end{array}$ & $\begin{array}{l}0.0 \\
0\end{array}$ \\
\hline $\begin{array}{l}\text { Within } \\
\text { the group }\end{array}$ & 23.2 & 62 & 0.374 & & \\
\hline Total & 32,258 & 65 & & & \\
\hline
\end{tabular}

Source: Computer SPSS version24.0 Output, field survey 2020.

This hypothesis was intended to identify the strength of the effect of Standard quality circle management practices on organization performance in south region of ethio telecom.

The ANOVA Table shows that Standard quality circle management practices affect organization performance in south region of ethio telecom at $(\mathrm{P} \leq 0.05)$ since the $\mathrm{F}$ probability value is 0.000 . The null hypothesis was rejected. This implies that Standard quality circle management practice had significant effect on organizational performance in ethio telecom south region

\section{MAJOR FINDINGS}

The first objective of this study was to assess the change management practices in ethio telecom of south region. Through the descriptive statistical analysis, an overall mean score was computed for each independent variable balanced scorecard management practices (BSC), kaizen and standard quality circle management practices). The study revealed that balanced scorecard management practices (Mean=3.578, 59 $\mathrm{SD}=0.775$ ) was relatively the most practiced in ethio telecom south region. Kaizen philosophy management practices (Mean=3.461, $\mathrm{SD}=0.722$ ) were practiced to moderate in ethio telecom south region, followed the Standard quality circle management practices with mean and standard deviation of (Mean=2.770, $\mathrm{SD}=0.673$ ) were relatively the least practiced. An overall balanced scorecard management practices, kaizen, and standard quality circle management practices with (Mean= 3.269, $\mathrm{SD}=0.723$ ) were occasionally practiced in ethio telecom south region. This study also discovered that balanced score card, kaizen and Standard quality circle management practices contributed to ethio telecom south region organizational performance to a great extent with an overall mean of(Mean=3.712, $\mathrm{SD}=0.954)$.

The second objective of the study was to examine the relationship between change management practices and organizational performance in ethio telecom south. This study revealed that there is a positive and statistically significant relationship between each independent variable and the dependent variable. The third objective of the study was to determine the effect of change management practices on performance in ethio telecom. The ANOVA test result revealed that the independent variable balanced scorecard, Kaizen, standard quality circle management practice statistically and significantly predict the dependent variable (organizational performance) at $\mathrm{p}<.005$ confidence interval. This implies that change management practice have significant effect on organizational performance in ethio telecom south region. The fourth objective of the study was to examine the level of performance in ethio telecom of south region. The ANOVA test result revealed that the independent variables statistically and significantly predict the dependent variable $(\mathrm{F}$ $=4.064, \mathrm{p}<.005)$. The regression analysis result further revealed that the predictor variable of kaizen management practices is statistically significant in predicting organizational performance because the p-value is less than alpha level of 0.05. However, the p-value for balanced scorecard management practices and standard quality circle management practices are greater than alpha level of 0.05 which indicated that they are not statistically significant in predicting the organizational performance despite literature has outlined them as important change management practices which shows that they are not properly addressed in ethio telecom south region.

\section{CONCLUSION}

It can be concluding from the study that all the change management practices (Balances scorecard practices, kaizen philosophy management practices and Standard quality circle management practices) were practiced occasionally. In addition, the study concluded that balanced scorecard, kaizen philosophy and standard quality circle management practices contributed to ethio telecom south region organizational performance to great extent. In relation to the relationship between balanced scorecard, kaizen and standard quality circle management practices and organizational performance, the study concluded that: There is a positive and significant relationship between balanced score card, kaizen and standard 


\section{International Journal of Engineering Applied Sciences and Technology, 2021 \\ Vol. 5, Issue 12, ISSN No. 2455-2143, Pages 53-62 \\ Published Online April 2021 in IJEAST (http://www.ijeast.com)}

quality circle management practices and organizational performance of ethio telecom south region. In addition, all change management practices namely balanced scorecard practices, kaizen philosophy management practices and Standard quality circle management practices have a moderate relationship with organizational performance of ethio telecom south region.

In relation to the effect of change management practices on performance in ethio telecom, the study conclude that: The ANOVA test result revealed that the independent variable balanced scorecard kaizen, standard quality circle management practice statistically and significantly predict the dependent variable that is organizational performance at $\mathrm{p}<$ .005 confidence interval. This implies that change management practice have significant effect on organizational performance in ethio telecom south region.

Moreover, in relation to the level of performance, the study concluded that: The predictor variable of kaizen management practices is statistically significant in predicting organizational performance because the $\mathrm{p}$-value is less than alpha level of 0.05. However, the p-value for balanced score card management practices and standard quality circle management practices are greater than alpha level of 0.05 which indicated that they are not statistically significant in predicting the organizational performance of ethio telecom south region.

\section{RECOMMENDATIONS}

Based on result obtained and the conclusions drawn, the following recommendations are forwarded;

1. The finding of this study shows that ethio telecom south region adopted balanced scorecard, kaizen philosophy and standard quality circle management practices occasionally. Moreover, the study confirmed that those management practices had a moderate positive relationship with organizational performance of ethio telecom south region. Moreover, kaizen is a predictor of organizational performance and statistically significant whereas, the rest are not.

2. This study more recommends that ethio telecom south region advised to practice the balanced score card, kaizen and Standard quality circle management regularly. If regularly practiced, the organization can significantly improve its organizational performance from the current position.

3. For successful of those change management practices, employees shall be properly trained on the change management. More importantly, managers and supervisors of ethio telecom of south region are advised to wait for change management especially in the telecommunication industry changes where occur every day.

4. In addition the training on kaizen philosophy is better on a continuous basis including work specific training to enhance employees' capability and caliber. Moreover, management of ethio telecom of south region advised to communicate, motivate and support employees and encourage effectively their participation.

\section{REFERENCES}

[1] Armstrong., M., Baron, A. "Performance Management" The New Realities. Great Britain: The Cromwell Press, Wiltshire.1998.

[2] Bashir,J.,\&Afzal,S. "Ethics based model for change management" Paper presented at South Asian International Conference on Management arranged by Academy for Global Business Advancement (AGBA) and COMSATS,2011.

[3] Burnes, A. Current thinking on the role of strategic communication in behavior and social change: Journal for Communication, Behavior and Social Change in South Asia. New Delhi, India,2014.

[4] Cawsey, T., Deszca, G., \& Ingols, C. Organizational Change, An action oriented toolkit (2nd Edition) Thousand Oaks, Californian: Sage Publications,2012.

[5] Cardy, R. L. "Performance management concepts, skills, and exercises. Armonk, NY: M. E. Sharpe 2004.

[6] Cummings, T., \& Worley, C. Organization development and change, 9 th ed.South Western: Cengage Learning Inc 2009.

[7] Davidson, J. "The Complete idiot's guide to change management", Indianapolis: Alpha Books 2002.

[8] Dubale, E.T. Telecommunication in Ethiopia, Multi-year expert meeting on service 2010.

[9] FA management model and factors driving performance in public organization Measuring Business Excellence. Vol. 13, Issue 4, Page, 2009.

[10] Federal Negarit Gazeta, Federal Democratic Republic of Ethiopia Council of Ministers, Regulation Number 197/2010.Garber, P.R. Managing change at work. American Society for Training \& Development, (2013).

[11] Hiatt J. M. \& Creasey T.J. Change management, The people side of change: Colorado: Prosci Inc.(2012).

[12] Hiatt, J.M.,\&Creasey, T.J. Change Management, The people side of change. (2nd ed.). Loveland, Colorado, USA: Prosci Research 2012.

[13] Hodges, R.L. Telecommunications: Drivers for Change. Technology Futures, 1995

[14] Kothari, C.R.. Research Methodology, Methods and Techniques. New - Delhi: NewAge international Publishers. Inc. 2006

[15] Jansson, N. Organizational change as practice, a critical.2013.

[16] Kumari, N. Balanced Scorecard for Superior Organizational Performance, European Journal of BusinessandManagementVol3,No.5, pp73-86, 2011.

[17] Maryam Beshtawil and Ayham Jaron, Review of Contemporary Business Research, Vol. 3(1), March 2014. 
[18] Mugenda M.O. \& Mugenda A. "Research methods" Qualitative and quantitative Approaches, Africa Center for technology studies, Nairobi, Kenya 2003.

[19] Mullins L. J., \& Christy. K.M., Management and Organizational Behavior, 6th Edition, Pitman Publishers, London, 2014.

[20] Pune Maharastra, Ethiopia - Telecoms, Mobile and Broadband Statistics and Analyses report. Mar-14, 2019.

[21] Raftery,E. "Transition Change Management Metrics For Success".Master Thesis, National University of Ireland, 2009.

[22] Sidikova, M., "The impact of change management on employee's motivation": A case of Cargotec Shared Service Centre. Bachelor Thesis. Turku University of Applied Sciences, 2011.

[23] Tang, C.,\&Gao, Y'.Intra-department communication and employees' reaction to organizational change, The moderating effect of emotional intelligence. Journal of Chinese Human Resources Management, 3(2),100117,2012 .

[24] Taye Estifanos Dubale Telecommunication in Ethiopia, 2010.

[25] TR Abdo Effect of Quality circle participation on employee perception and attitude:Journal of scientific and Industrial research,Vol65,December2006,pp970 $976,2006$.

[26] Walmsley, B. "Managing Change.Chartered Management Institute".England: Hodder Education,2009. 